\title{
Changes in plant responses induced by an arthropod influence the colonization behavior of a subsequent herbivore
}

\author{
Diego B Silva, ${ }^{a}, c^{*} \odot$ Alejandro Jiménez, ${ }^{a, b}$ Alberto Urbaneja, ${ }^{c} \odot$

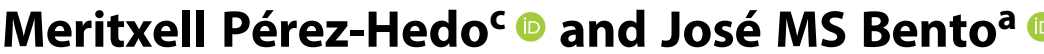

\begin{abstract}
BACKGROUND: Plants in nature can be sequentially attacked by different arthropod herbivores. Feeding by one arthropod species may induce plant-defense responses that might affect the performance of a later-arriving herbivorous species. Understanding these interactions can help in developing pest-management strategies. In tomato, the sweet-potato whitefly Bemisia tabaci and the two-spotted spider mite Tetranychus urticae are key pests that frequently cohabit on the same plant. We studied whether colonization by one species can either facilitate or impede later colonization of tomato plants by conspecific or heterospecific individuals.

RESULTS: B. tabaci females showed a strong preference for and increased oviposition on plants previously colonized by conspecifics. In contrast, plants infested with $T$. urticae repelled B. tabaci females and reduced their oviposition rate by $86 \%$. Although females of $T$. urticae showed no preference between conspecific-infested or uninfested plants, we observed a $50 \%$ reduction in the number of eggs laid on conspecific-infested plants. Both herbivorous arthropods up-regulated the expression of genes involving the jasmonic acid and abscisic acid pathways, increasing emissions of fatty-acid derivatives, but only $B$. tabaci increased the expression of genes related to the salicylic acid pathway and the total amount of phenylpropanoids released. Terpenoids were the most abundant compounds in the volatile blends; many terpenoids were emitted at different rates, which might have influenced the arthropods' host selection.
\end{abstract}

CONCLUSION: Our results indicate that $B$. tabaci infestation facilitated subsequent infestations by conspecifics and mites, while T. urticae infestation promoted herbivore-induced resistance. Based on both the molecular and behavioral findings, a novel sustainable pest-management strategy is discussed.

(c) 2021 Society of Chemical Industry.

Keywords: plant defense; herbivore behavior; abscisic acid; jasmonic acid; salicylic acid; herbivore-induced plant volatiles

\section{INTRODUCTION}

Plants in agroecosystems commonly interact with a wide range of herbivorous species that may cause severe losses of yield if not properly managed. ${ }^{1,2}$ Throughout their evolution, plants have developed many defense strategies involving a wide range of physical and chemical barriers. Plant defensive responses to herbivory include changes in primary and secondary metabolites through activation of phytohormones. These changes in the plant phenotype may be elicited differently by many biotic factors, such as the species of attacking arthropod and its feeding mode, or the sequence of species that colonize a plant. ${ }^{3-5}$

The expression of herbivore-induced plant defenses, which is modulated mainly by phytohormones, significantly affects hostplant selection by herbivores. Phloem-feeding herbivores such as whiteflies (Hemiptera: Aleyrodidae) induce changes in herbivore-induced plant volatiles (HIPVs) that are mediated by the salicylic-acid (SA) pathway, while leaf-chewing herbivores such as caterpillars (Lepidoptera) and beetles (Coleoptera) have been found to induce the jasmonic-acid (JA) signaling pathway. ${ }^{4,6}$ Herbivores with short stylets, such as mites, that feed on the cell contents are reported to activate both the SA and JA pathways. ${ }^{7}$ These physiological changes may reduce or increase plant defenses and modify plant-insect interactions through direct defenses such as the production of toxic proteins with antinutritive effects or indirect defenses such as inducing the production of HIPVs. The induction of these volatiles differs qualitatively and quantitatively among herbivore species, ${ }^{8-10}$ which can positively or negatively affect the host-searching behavior of subsequently attacking herbivores. ${ }^{1-14}$

\footnotetext{
* Correspondence to: DB Silva, Department of Entomology and Acarology, University of São Paulo, Piracicaba, SP 13418-900, Brazil. E-mail: diegobs182@yahoo.com.br
a Department of Entomology and Acarology, Luis de Queiroz College of Agricul- ture, University of São Paulo, Piracicaba, Brazil

b Department of Entomology, University of Tolima, Ibagué, Colombia

c Instituto Valenciano de Investigaciones Agrarias, Centro de Protección Vegetal y Biotecnología, Valencia, Spain
} 
Increased plant resistance can repel a subsequent herbivore attack, ${ }^{14-19}$ but in some cases previous herbivore infestation increases the susceptibility of a plant, thus facilitating arthropod aggregations. ${ }^{20-22}$ For instance, initial herbivory by chewing flea beetles (Coleoptera: Chrysomelidae) on plants of Solanum dulcamara L. (bittersweet nightshade) lowered the occurrence of conspecifics, whereas red spider mites, Oligonychus ilicis (McGregor) (Acari: Tetranychidae), infesting coffee plants (Coffea arabica L.) facilitated a subsequent infestation by mealybugs (Hemiptera: Pseudococcidae). ${ }^{20,23}$ Some arthropods, such as the brown planthopper, Nilaparvata lugens (Stål) (Hemiptera: Delphacidae), and the cottonworm, Spodoptera littoralis (Boisduval) (Lepidoptera: Noctuidae), manipulate the plant metabolism to enhance its susceptibility to conspecifics. ${ }^{24,25}$ Studies of the effects of attacks on plants by various herbivore species have focused mainly on chewing insects, interaction between chewing and phloem-feeding herbivores, or multiple herbivory. ${ }^{26,27}$ Information on intra- and interspecific interactions between phloemfeeders and cell-content feeders is sparse. ${ }^{28-30}$ However, we noted that in a tomato greenhouse crop those plants infested by the two-spotted spider mite Tetranychus urticae Koch (Acari: Tetranychidae) are less susceptible to attack by the phloemfeeding sweet-potato or silverleaf whitefly Bemisia tabaci (Gennadius) (Hemiptera: Aleyrodidae) (Alberto Urbaneja, IVIA, Spain, personal communication). The factors that promote plant resistance associated with interactions between these arthropod pests are unknown, and a detailed exploration of this negative interaction is needed.

T. urticae and B. tabaci are cosmopolitan species that can reproduce on a wide range of host plants and cause economically important losses in cultivated plants. ${ }^{31-33}$ Both arthropod species are key pests of tomato crops worldwide. ${ }^{34-36} T$. urticae feeds on the epidermis and punctures parenchyma cells, leaving lightcolored stipples on the leaf surface and injecting phytotoxic compounds that reduce photosynthesis and decrease yield. ${ }^{37,38}$ T. urticae activates both the JA and SA signaling pathways, which function differently in plant-arthropod interactions. ${ }^{15,28,39-41}$ For instance, up-regulation of plant defenses such as proteinase inhibitors and allelochemicals caused by T. urticae is correlated with significantly poor performances of the cucumber moth, Diaphania indica (Saunders) (Lepidoptera: Pyralidae), and the red spider mite, T. evansi Baker (Acari: Tetranychidae). In contrast, females of Myzus persicae (Sulzer) (Hemiptera: Aphididae) chose and produced more offspring on plants previously infested with T. urticae. ${ }^{28,29,42}$

B. tabaci damages host plants by removing the phloem sap and excreting honeydew, fostering the growth of fungi that cause sooty mold and also causing physiological disorders, such as irregular ripening of tomato fruits and, more importantly, vectoring important plant viruses. ${ }^{33,36}$ Its wide host range enables B. tabaci to compete intensively with other pests. ${ }^{43,44}$ Competition may be either direct, when damage to a plant by one herbivore species deprives a second species of that resource, or indirect, when competition is plant-mediated. ${ }^{15,45,46}$ Colonization of cowpeas and tobacco plants by whiteflies increases the tapping behavior of $T$. truncatus Ehara (Acari: Tetranychidae), indicating reduced palatability, and decreases the attraction of adult females of Spodoptera litura (Fabricius) (Lepidoptera: Noctuidae), while infestation of tomato plants by $B$. tabaci increases subsequent colonization by conspecifics. ${ }^{22}$

Despite the agricultural importance of T. urticae and B. tabaci, and the several studies of their ability to modulate plant responses, to the best of our knowledge the effects of plantmediated responses on the host-related behaviors of these interacting arthropods have not yet been addressed. Therefore, based on our above-mentioned field observations, we hypothesized that infestation by one arthropod pest would induce plants to develop defenses, and consequently would interfere with colonization of the same plants by a different arthropod pest. To investigate the factors that modulate this resistance, we employed a combination of behavioral assays, molecular biology, and chemical analysis of plant volatiles.

These studies allowed us to infer which sequence of attacks in multiple infestations of a tomato crop is more likely to occur, which can assist in the development of pest-management strategies.

\section{MATERIALS AND METHODS}

\subsection{Plants and arthropods}

Seeds of tomato (Solanum lycopersicon L. cv. Santa Clara) were sown on sterilized substrate (Tropstrato HA Hortaliças, Vida Verde, Mogi Mirim, SP, Brazil) and irrigated daily. Seedlings $1 \mathrm{~cm}$ high were transplanted to 1.8-L plastic pots, each containing this substrate mixed with $20 \mathrm{~g}$ of nitrogen, phosphorus and potassium (NPK) 4-14-8 Vitaplant fertilizer (Nutriplan, Cascavel, Brazil). Tomato plants were maintained in a greenhouse $\left[25 \pm 2{ }^{\circ} \mathrm{C}, 70\right.$ $\pm 10 \%$ relative humidity $(\mathrm{RH}), 12: 12 \mathrm{~h}$ light (L):dark (D)] and irrigated daily. Plants 35 days old, $25 \mathrm{~cm}$ tall, and with five expanded leaves were used in the experiments.

The initial population of the spider mite $T$. urticae was provided from the stock colony in the Acarology Laboratory at ESALQ/USP (Piracicaba, São Paulo, SP, Brazil). Spider mites were maintained on discs of jack-bean leaves, Canavalia ensiformes (L.), placed on wet sponges in Petri dishes ( $20 \mathrm{~cm}$ in diameter). Leaf edges were encircled by wet cotton threads ( $2 \mathrm{~cm}$ thick) to prevent the mites from escaping and to supply water. The sponge was watered every 2 days and the leaves were changed every 3 days. The colony was maintained in a climate-controlled room $\left(28 \pm 2{ }^{\circ} \mathrm{C}, 70\right.$ $\pm 10 \% \mathrm{RH}, 12: 12 \mathrm{~h}$ L:D). Spider mites of the eighth generation were used in the experiments.

Whiteflies, B. tabaci biotype B, were provided from the stock colony maintained at the Agronomic Institute of Campinas (Campinas, SP). Colonies were maintained in greenhouse conditions $\left(25 \pm 2{ }^{\circ} \mathrm{C}, 70 \pm 10 \% \mathrm{RH}, 12: 12 \mathrm{~h} \mathrm{~L}: \mathrm{D}\right)$ in insect-proof cages $(60 \times 40 \times 40 \mathrm{~cm})$ on cabbage plants (Brassica oleracea L. var. acephala DC. cv. Manteiga). The plants were grown in plastic pots containing a soil mix composed of shredded pine bark, peat, and expanded vermiculite with $60 \% \mathrm{w} / \mathrm{w}$ moisture content (Tropstrato HT; Vida Verde, Mogi Mirim, SP, Brazil). Whiteflies of the tenth generation were used in the experiments.

\subsection{Plant treatments}

Tomato plants were subjected to the following treatments:

- Uninfested tomato plants. Intact tomato plants grown in the above-mentioned greenhouse.

- B. tabaci-infested plants. To obtain tomato plants infested with eggs, nymphs, and adults of $B$. tabaci, the method described by Lins et al. ${ }^{47}$ was followed. Fifty adults (sex ratio $1: 1$ ) were released into a cage $(60 \times 30 \times 40 \mathrm{~cm})$ containing one tomato plant and left undisturbed for 10 days. Based on the number of eggs laid per day, egg development time, percentage of eggs 
hatched, and survival, we estimated that a mean of 630 eggs and 270 nymphs was produced at the end of day $10 .{ }^{48}$

- T. urticae-infested plants. One hundred adult females of T. urticae were equally distributed onto all leaflets (three mites per leaflet) of five tomato leaves. Plants were kept individually in mite-proof screen cages $(60 \times 30 \times 40 \mathrm{~cm})$ and the mites were allowed to feed on the plants for $24 \mathrm{~h}$ before the assays. Farmax Vaseline (Amaral, Divinópolis, MG, Brazil) was applied to the petioles of all five leaves on which mites were released to prevent them from moving to another leaf. The leaf petioles of the control and B. tabaci-infested plants were also sealed with Vaseline. In addition, mites, whitefly eggs, and nymphs were maintained on tomato plants during the bioassays. Infested and uninfested plants were kept in different greenhouses (under the same abiotic conditions) and were transferred from the greenhouse to the laboratory just before the beginning of each assay series.

\subsection{Olfactometer assays}

Responses of $B$. tabaci females to HIPVs were assessed in a glass $Y$ tube olfactometer $(4.0 \mathrm{~cm}$ in diameter, main arm $9 \mathrm{~cm}$ long, side arms $10 \mathrm{~cm}$ long, $70^{\circ}$ angle between side arms). The olfactometer was positioned horizontally and connected to an ARS volatile collection system (Analytical Research Systems, Gainesville, FL, USA). Each olfactometer side arm was connected to a $15-\mathrm{L}$ glass vessel containing a single tomato plant. Plastic pots $(1.8 \mathrm{~L})$ in which the tomato plants were growing were wrapped with aluminum foil. The inlet air flow was adjusted to $0.2 \mathrm{~L} \mathrm{~min}^{-1}$ for each side arm. The glass vessels were kept behind a black panel to prevent the insects from visually detecting the plants. The olfactory responses of $T$. urticae females were also assessed using the same ARS system and Y-tube. In this case, to aid the mites in traveling, a Yshaped 4-mm diameter glass wire was placed in the core of the Y-tube olfactometer and the inlet air flow was adjusted to $1.5 \mathrm{~L} \mathrm{~h}^{-1}$ for each side arm.

For the assay, a single $B$. tabaci female, 1-7 days old, was starved for $2 \mathrm{~h}$ in a 2-mL tube containing a piece of moistened cotton and sealed with cotton. The female was then introduced into the main arm of the olfactometer and observed for up to $10 \mathrm{~min}$. Females were considered to have made a choice when they crossed a line drawn $8 \mathrm{~cm}$ from the branching point of the Y-tube. Females that did not choose a side arm within 10 min were considered to be nonresponsive and were excluded from the data analysis. Each female was tested only once. For T. urticae, females 1-4 days old were starved for $24 \mathrm{~h}$ in a Petri dish $5 \mathrm{~cm}$ in diameter that contained a piece of moistened cotton and was covered on the top with Parafilm to prevent the mites from escaping. Each female was placed individually at the beginning of the basal arm of the wire by means of a soft brush. Females were allowed 5 min to make a choice, and were considered to have made a choice when they crossed a line drawn $3 \mathrm{~cm}$ from the branching point of the $Y$ tube. Females that did not choose a side arm within 5 min were considered to be nonresponsive and were excluded from the data analysis.

The odor source was switched after two replicates to avoid positional bias. Four supplemental $120-\mathrm{cm}$ lights (GreenPower LED DR/W $18 \mathrm{~W}$, Philips, Netherlands) were positioned $50 \mathrm{~cm}$ above the olfactometer to provide uniform light (total light intensity of $40 \mu \mathrm{moles} / \mathrm{m}^{2} \mathrm{~s}$ ) during the testing period. After 10 females had been tested, the $Y$-tube and glass vessels were washed with neutral soap and ethanol (70\%) and dried. A total of 30 replicates (responses) was performed for each treatment and arthropod species, using at least three pairs of tomato plants on three different days. Each day was treated as a block in a randomized complete-block design. Bioassays of both arthropod species were carried out in a climate-controlled room at $25 \pm 2{ }^{\circ} \mathrm{C}$ and 70 $\pm 10 \% \mathrm{RH}$ between 10:00 and 12:00 $\mathrm{h}$ and again between 14:00 and 16:00 h.

\subsection{Host-related behavior}

To assess the effects of prior infestation with either herbivore (whitefly or mite) on host selection by the next herbivore (whitefly or mite), we used a different experimental arrangement for each species because of their oviposition behavior. For a whitefly experiment, after the infestation period, each tomato plant was covered with organza, leaving the third completely developed leaf from the bottom exposed for a choice/oviposition by the adult whitefly. Any mites or whiteflies on this leaf were carefully removed before the experiment. Briefly, we turned the leaf upside down and with the aid of a fine strong brush and a headband magnifier $(20 \times)$ removed them, taking care not to further damage the leaf. Also, prior to the behavior tests plants were left for $2 \mathrm{~h}$ to allow any undesirable volatile compounds resulting from the plant manipulation to disseminate. The experimental unit consisted of a cage $(60 \times 40 \times 40 \mathrm{~cm})$ with two plants, one for each treatment. One adult female, 1-7 days old, was placed in a glass tube in the middle of the cage.

The arena for the mite host selection consisted of a rectangular plastic box $(30 \times 15 \times 10 \mathrm{~cm})$ with one hole $(7-\mathrm{cm}$ diameter) in each side of the box. One leaf from an uninfested and one from an infested plant were inserted into the arena through the holes without removing the leaves from the plants. Inside the arena, two similarly sized leaflets $\left(5-6 \mathrm{~cm}^{2}\right)$ were placed on watersaturated cotton in Petri dishes ( $6 \mathrm{~cm}$ diameter) and connected with a bridge $(4 \times 0.5 \mathrm{~cm})$ made of Teflon tubing cut in half lengthwise. One female mite, 3 or 4 days old, was carefully placed in the middle of the bridge to allow it to access the leaflets (adapted from Walzer et al. ${ }^{49}$ ). We removed the arthropods from the infested leaves as described above.

Some arthropods are able to use long- and short-distance volatile and tactile cues for decisions on patch choice and oviposition. ${ }^{50}$ Observations of a female over time may indicate what type of cue is used. Therefore, the first choice of a female (mite and whitefly) was observed and the female's position was recorded after 6 and 24 h. Host preference was determined by comparing the number of females in the two treatments after $24 \mathrm{~h}$. Oviposition-site preference was determined by comparing the number of eggs in one of the two treatments after $24 \mathrm{~h}$. Each choice experiment was repeated 30 times in a climate-controlled room at $25 \pm 2{ }^{\circ} \mathrm{C}$ and $70 \pm 10 \% \mathrm{RH}$.

\subsection{Plant gene-expression analysis}

The apical part of the tomato plants (cv. Santa Clara), defined as the first $5 \mathrm{~cm}$ of the plant formed by the apical developing stem and leaves, was subjected to targeted gene-expression analysis to detect: (i) ASR1 (abscisic acid-stress ripening protein 1), a marker gene for abscisic acid (ABA), (ii) PIN2 (wound-induced proteinase inhibitor II precursor), a marker gene for jasmonic acid (JA), and (iii) PR1 (basic PR-1 protein precursor), a marker gene for the salicylic acid (SA) signaling pathway. EF1 (elongation factor-1) was used as a standard control gene for normalization. The nucleotide sequences of the gene-specific primers are described in Table 1. Three samples of the apical part of the tomato plant, as defined above, collected from B. tabaci-infested 


\begin{tabular}{|lll|}
\hline Table 1. & Forward and reverse sequences of $A S R 1, P I N 2, P R 1$, and the constitutive gene $E F 1$ & Reverse primer $\left(5^{\prime} \rightarrow 3^{\prime}\right)$ \\
\hline Gene & Forward primer $\left(5^{\prime} \rightarrow 3^{\prime}\right)$ & 5-AGCTTCGTGGTGCATCTC-3 \\
\hline EF1 & 5-GATTGGTGGTATGGAACTGTC-3 & 5-GTGTTGTGGCATGTTGTGA-3 \\
ASR1 & 5-ACACCACCACCACCACCTGT-3 \\
$P R 1$ & 5-CCGTGCAATTGTGGTGTC-3 & 5-GAGTGGGCCAGACTACTTGAGT-3 \\
PIN2 & 5-GAAAATCGTTAATTATCCCAC-3 & 5-ACATACAAACTTCCATCTTA-3 \\
\hline
\end{tabular}

(plants exposed to $100 \mathrm{~T}$. urticae adults for $24 \mathrm{~h}$ prior to the assay), B. tabaci-infested (plants exposed to $50 \mathrm{~B}$. tabaci adults for 10 days prior to the assay), and control plants were removed and immediately ground in liquid nitrogen. We have carried out an extended sampling time (10 days) for defense-related gene to match the behavior assays and also due to the previous observed up-regulation of the same genes 2 weeks after exposing the plant to a piercing-sucking insect. ${ }^{14}$ For each leaf sample, $100 \mathrm{mg}$ was used to extract the total RNA, with minor modifications to increase yield. After homogenization in liquid nitrogen, total RNA was extracted using TRIzol reagent (Invitrogen, Carlsbad, CA, USA) according to the manufacturer's instructions. ${ }^{17,19}$ After the sample was homogenized with TRIzol, chloroform was added to separate the RNA from protein and DNA, and then isopropanol and $1.2 \mathrm{mmol} \mathrm{L}^{-1} \mathrm{NaCl}$ were added to precipitate the RNA. The resulting RNA pellets were washed twice with $70 \%$ ethanol, dried at room temperature, and eluted in water. The RNA was quantified and then treated with a Turbo DNA-free DNase kit (Applied Biosystems) to eliminate any traces of genomic DNA, according to the manufacturer's protocol. cDNA was synthesized by adding to the samples $\left(1 \mu \mathrm{g} \mathrm{L}^{-1}\right) \mathrm{RT}$ buffer, $10 \mu \mathrm{mol} \mathrm{L}{ }^{-1}$ Oligo dT, and Prime Script RT Reagent Kit (Perfect Real Time) (Takara Bio USA, Mountain View, CA, USA). The reaction mixture was incubated in the thermocycler for $15 \mathrm{~min}$ at $37^{\circ} \mathrm{C}$ and $5 \mathrm{~s}$ at $85^{\circ} \mathrm{C}$. Specific forward and reverse primers $(0.5 \mu \mathrm{L}$ ) (Table 1$)$ were added to $5 \mu \mathrm{L}$ of SYBR Green/ROX qPCR Master Mix and $1 \mu \mathrm{L}$ of CDNA, and then brought to $10 \mu \mathrm{L}$ total volume with Milli-Q sterile water. PCR reactions were run according to the manufacturer's recommendations. Quantitative PCR was carried out using the LightCycler 480 System (Roche Molecular Systems, Inc., Rotkreuz, Switzerland); the protocol consisted of $95^{\circ} \mathrm{C}$ for $10 \mathrm{~min}$ followed by 40 cycles of $95{ }^{\circ} \mathrm{C}$ for $15 \mathrm{~s}, 56^{\circ} \mathrm{C}$ for $30 \mathrm{~s}$, and $72{ }^{\circ} \mathrm{C}$ for $30 \mathrm{~s}$. Melting-curve analysis was performed at $95^{\circ} \mathrm{C}$ for $5 \mathrm{~s}, 60^{\circ} \mathrm{C}$ for $1 \mathrm{~min}$, and finally a gradual temperature increase to $95^{\circ} \mathrm{C}$. Data acquisition and calculation were performed with the thermocycler software, and the data were entered and analyzed in Microsoft Excel.

\subsection{Headspace collection and analysis of plant volatiles}

Volatiles from different groups of uninfested and herbivoreinfested tomato plants (treatments ii-v described above) and pots filled with soil (blank) were collected under laboratory conditions at $24 \pm 1{ }^{\circ} \mathrm{C}$ and $70 \pm 10 \% \mathrm{RH}$ from 10:00-12:00 $\mathrm{h}$ and 14:00$16: 00 \mathrm{~h}$, in a push-pull volatile collection system (Analytical Research Systems).

Before the volatiles were collected, plant pots were carefully wrapped with aluminum foil to avoid trapping volatiles from the plastic and soil, and were enclosed individually in 15-L glass vessels. The volatile collections were randomly distributed between treatments. Six plants per treatment were sampled for $2 \mathrm{~h}$ (flow rate $0.8 \mathrm{~L} \mathrm{~min}^{-1}$ ) using a trap filled with $30 \mathrm{mg}$ of Hayesep
(Supelco, Bellefonte, PA, USA). Volatile traps were immediately eluted with $150 \mu \mathrm{L}$ of hexane (Merck, Kenilworth, NJ, USA) mixed with $30 \mu \mathrm{L}$ of nonyl acetate solution (Sigma-Aldrich, St. Louis, MO, USA) at $10 \mathrm{ng} \mu \mathrm{L}^{-1}$, used as internal standard. All extracts were stored at $-80{ }^{\circ} \mathrm{C}$ for $3-5$ days until analysis. Immediately after the volatiles were collected, the dry weight of the plant shoot was determined.

The headspace analysis was performed by gas chromatography (Shimadzu, GC-2010 Gas Chromatograph) with a flame ionization detector (GC-FID) operated at $280^{\circ} \mathrm{C}$. Quantification was based on comparing the area under the GC-FID peak with the internal standard and standardized per unit of fresh-shoot biomass $(\mathrm{g})$ of each replicate. Briefly, a 2- $\mu \mathrm{L}$ aliquot of each sample was injected in the pulsed splitless mode into a HP-1 capillary column (Agilent J\&W GC Columns, Santa Clara, CA, USA; $30 \mathrm{~m}, 0.25 \mathrm{~mm}$ ID, $0.25 \mu \mathrm{m}$ film thickness). The carrier gas was high-purity helium

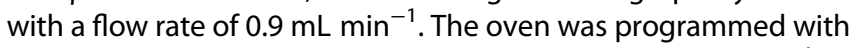
an initial temperature of $40{ }^{\circ} \mathrm{C}$ for $5 \mathrm{~min}$, raised at $5{ }^{\circ} \mathrm{C} \mathrm{min}^{-1}$ to $150{ }^{\circ} \mathrm{C}$, held for $1 \mathrm{~min}$, and then raised to $200{ }^{\circ} \mathrm{C}$ at $20^{\circ} \mathrm{C} \mathrm{min}{ }^{-1}$, followed by a post-run of $5 \mathrm{~min}$ at $250{ }^{\circ} \mathrm{C}$. GCsolution (version 2.32.00, Shimadzu) was used for signal acquisition and peak integration.

The most representative sample from each treatment, selected based on the mean quantity of the compounds and with the fewest contaminants compared to blank samples, was also analyzed with a gas chromatograph (Agilent 6890 Series GC system G1530A) coupled to a mass spectrometer. The GC-MS operated in electron impact mode (Agilent 5973 Network Mass Selective Detector; transfer line $230{ }^{\circ} \mathrm{C}$, source $230{ }^{\circ} \mathrm{C}$, ionization potential $70 \mathrm{eV}$, scan range 33-280 amu). Briefly, a 2- $\mu \mathrm{L}$ aliquot of each sample was injected in the pulsed splitless mode into an HP-1 capillary column (Alltech Associates, Deerfield, IL, USA; $30 \mathrm{~m}$, $0.25 \mathrm{~mm}$ ID, $0.25 \mu \mathrm{m}$ film thickness). Helium (0.9 $\left.\mathrm{mL} \mathrm{min}{ }^{-1}\right)$ was used as the carrier gas. The $\mathrm{GC}$ oven temperature was initially held at $40{ }^{\circ} \mathrm{C}$ for $3 \mathrm{~min}$, raised to $100{ }^{\circ} \mathrm{C}$ at $8{ }^{\circ} \mathrm{C} \mathrm{min}-1$ and then to $200{ }^{\circ} \mathrm{C}$ at $5{ }^{\circ} \mathrm{C} \mathrm{min}^{-1}$, followed by a post-run of $5 \mathrm{~min}$ at $250{ }^{\circ} \mathrm{C}$. The volatiles detected were identified by comparing their mass spectra with those of the NIST 11 library and with published retention times. ${ }^{51,52}$ Injection of authentic standards (except for carene, $\delta$-elemene, and $\beta$-elemene) and calculation of the linear retention index (LRI) of each compound were additional criteria for identification of the compounds.

\subsection{Data analysis}

To investigate whether the preferences of the arthropods differed when various combinations of volatile sources (olfactometer experiment) or combinations of volatile sources plus visual cues (host-selection experiment) were offered, the data sets were analyzed with a chi-square goodness-of-fit test. The response variable was the proportion of insects responding to one of the host sites, with the null hypothesis that the treatments chosen would show a 
$50 \%$ distribution. The oviposition rates after $24 \mathrm{~h}$ were compared within each choice situation between the two treatments, using Student's $t$-test for dependent samples. Prior to analysis, the raw data were tested for normality and homogeneity of variances, using the Shapiro-Wilk and Bartlett's tests, respectively. Oneway ANOVA followed by a comparison of means (Tukey's test) was applied to identify differences in the transcriptional responses of the $A S R 1, P I N 2$, and $P R 1$ genes in the apical parts of B. tabaci- and T. urticae-infested and intact tomato plants. The volatile emissions were initially tested for normality and homogeneity of variances, using the Shapiro-Wilk and Bartlett tests, respectively. As the distributions did not meet the assumptions for the parametric tests even after transformation, the data were analyzed using the nonparametric Kruskal-Wallis test followed by the average fit test of the Monte Carlo method. The quantity of each compound was considered to differ among treatments based on a nonoverlap of 1.5 times each standard error around the means. ${ }^{53,54}$ A principal component analysis (PCA) was then performed to evaluate whether the treatment groups could be separated by quantitative and/or qualitative differences in their volatile blends. The composition of the volatiles was analyzed using R software version 3.1.1 (www.R-project.org).

\section{RESULTS}

\subsection{Olfactometer assays}

B. tabaci females did not discriminate between the odors from uninfested tomato plants (Fig. $1 ; \chi^{2}=1.23, P=0.273$ ) or tomato plants infested with $T$. urticae (Fig. $1 ; \chi^{2}=8.53, P=0.273$ ) in comparison to clean air. However, they were attracted more often to the volatiles from tomato plants infested with conspecifics than to clean air (Fig. $1 ; \chi^{2}=8.53, P \leq 0.001$ ).

When $B$. tabaci females were offered a choice between odors from uninfested tomato plants and odors from conspecificinfested plants, they showed no preference (Fig. $1 ; \chi^{2}=0.53$, $P=0.465)$. However, females oriented to odors from uninfested tomato plants more often than to odors from $T$. urticae-infested plants (Fig. $1 ; \chi^{2}=6.53, P=0.010$ ). Females of $B$. tabaci also preferred odors from conspecific-infested plants over odors from $T$. urticae-infested plants (Fig. $1 ; \chi^{2}=8.53, P \leq 0.001$ ).

T. urticae females were attracted to odors from uninfested tomato plants (Fig. $2 ; \chi^{2}=10.8, P \leq 0.001$ ) and plants infested with $B$. tabaci (Fig. $2 ; \chi^{2}=4.8, P=0.028$ ) more often than to clean air, while odors from tomato plants infested with conspecifics did not attract them more than clean air did (Fig. $2 ; \chi^{2}=0.13, P=0.715$ ).

$T$. urticae females oriented significantly more toward the volatiles from $B$. tabaci-infested tomato plants than toward uninfested plants (Fig. $2 ; \chi^{2}=6.53, P=0.010$ ). Nevertheless, they did not show a preference between volatiles from uninfested tomato plants and plants infested with conspecifics (Fig. $2 ; \chi^{2}=0.53$, $P=0.465)$. Therefore, the odors from $B$. tabaci-infested plants were more attractive than the odors from $T$. urticae-infested plants (Fig. $2 ; \chi^{2}=6.53, P \leq 0.010$ ).

\subsection{Host-related behavior}

When visual, odor, and tactile cues were present, $B$. tabaci females were highly attracted to conspecific-infested plants in preference to uninfested tomato plants (Fig. 3(a); $6 \mathrm{~h}: \chi^{2}=6.54, P=0.014$; $\left.24 \mathrm{~h}: \chi^{2}=8.78, P \leq 0.001\right)$. The number of eggs was three times higher on plants previously colonized by B. tabaci (Fig. 5(a); $t=6.37 ; P=0.0076)$. On the other hand, whiteflies were found more often on uninfested plants than on $T$. urticae-infested plants at 6 and 24 h (Fig. 3(b); 6 h: $\chi^{2}=5.17, P=0.037 ; 24$ h: $\chi^{2}=6.54, P=0.014$ ), and consequently larger numbers of eggs were found on uninfested plants (Fig. 5(a); $t=3.004 ; P=0.0036$ ). Finally, the numbers of whitefly females and eggs $24 \mathrm{~h}$ afterward were higher on the whitefly-infested tomato plants than on the $T$. urticae-infested plants (Fig. 3(c); $\chi^{2}=4.6, P=0.037$ ); (Fig. 5(a); $t=2.531 ; P=0.0352$ ).

Females of $T$. urticae significantly preferred $B$. tabaci-infested tomato plants over uninfested plants after $24 \mathrm{~h}$ (Fig. 4(a); $\left.\chi^{2}=4.6, P=0.038\right)$, but the number of $T$. urticae eggs was similar between the two treatments (Fig. 5(b); $t=0.491, P=0.764$ ). Although $T$. urticae females were distributed equally between

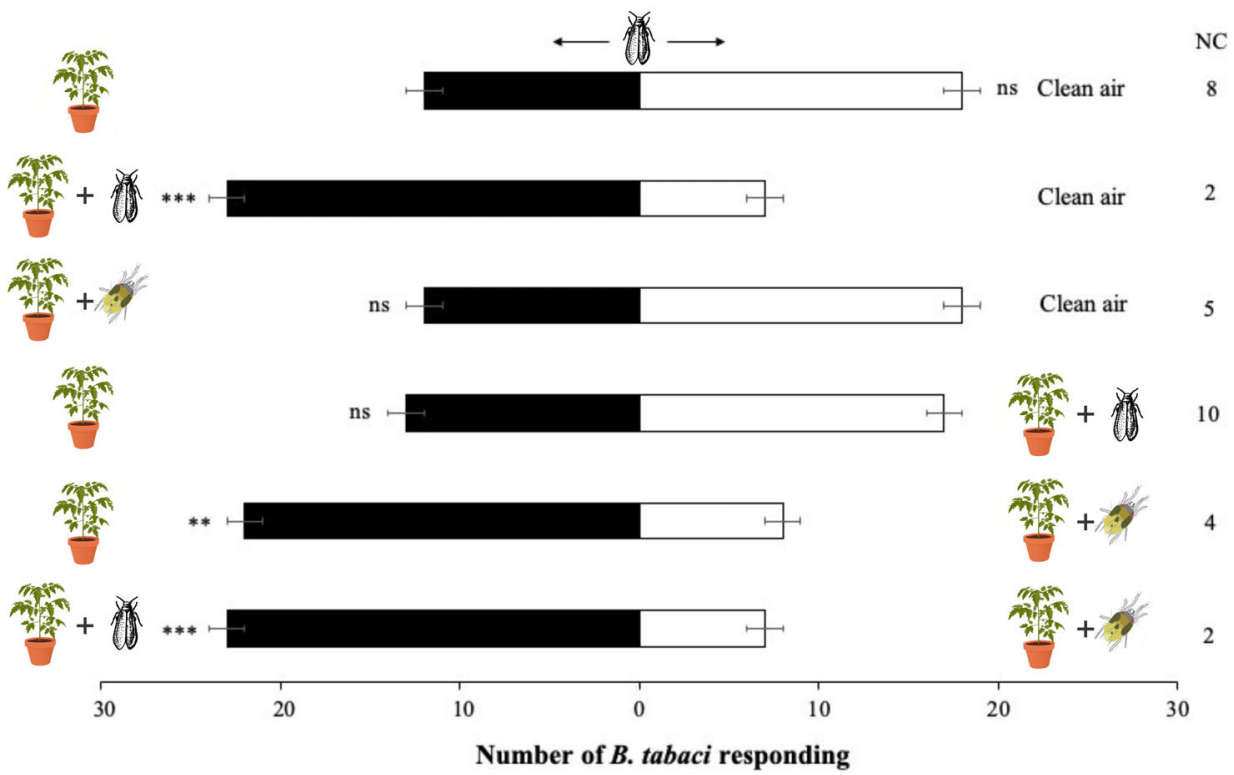

Figure 1. Responses of Bemisia tabaci females $(n=30)$ to volatiles from uninfested tomato plants, tomato plants infested with $B$. tabaci, and tomato plants infested with Tetranychus urticae in a Y-tube olfactometer. The horizontal axis represents the number of $B$. tabaci that moved toward the volatile sources. NC indicates the number of tested individuals that did not make a choice. Chi-square test $\left(\chi^{2}\right)$ : ${ }^{* * *} P<0.001,{ }^{* *} P<0.01,{ }^{*} P<0.05$, ns $P>0.05$. 


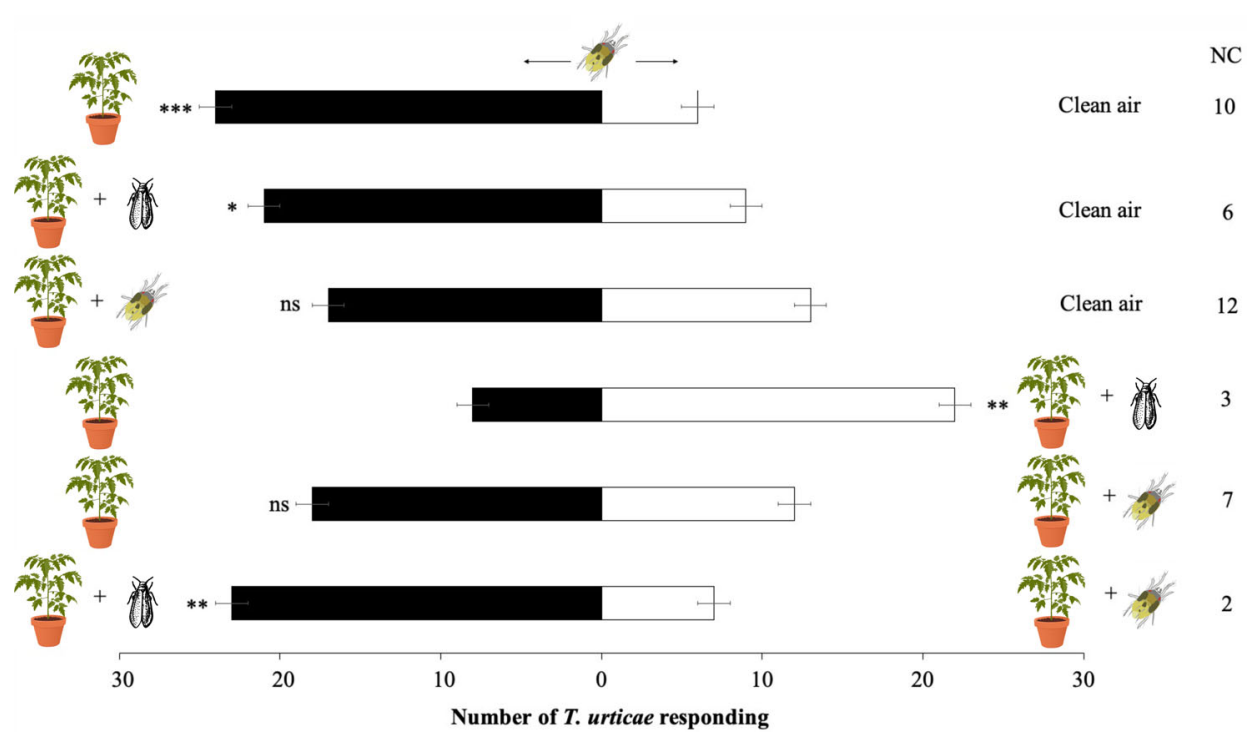

Figure 2. Responses of Tetranychus urticae females $(n=30)$ to volatiles from uninfested tomato plants, tomato plants infested with Bemisia tabaci, and tomato plants infested with $T$. urticae in a Y-tube olfactometer. The horizontal axis represents the number of $T$. urticae that moved toward the volatile sources. NC indicates the number of tested individuals that did not make a choice. Chi-square test $\left(\chi^{2}\right):{ }^{* * *} P<0.001,{ }^{* *} P<0.01,{ }^{*} P<0.05, \mathrm{~ns} P>0.05$.

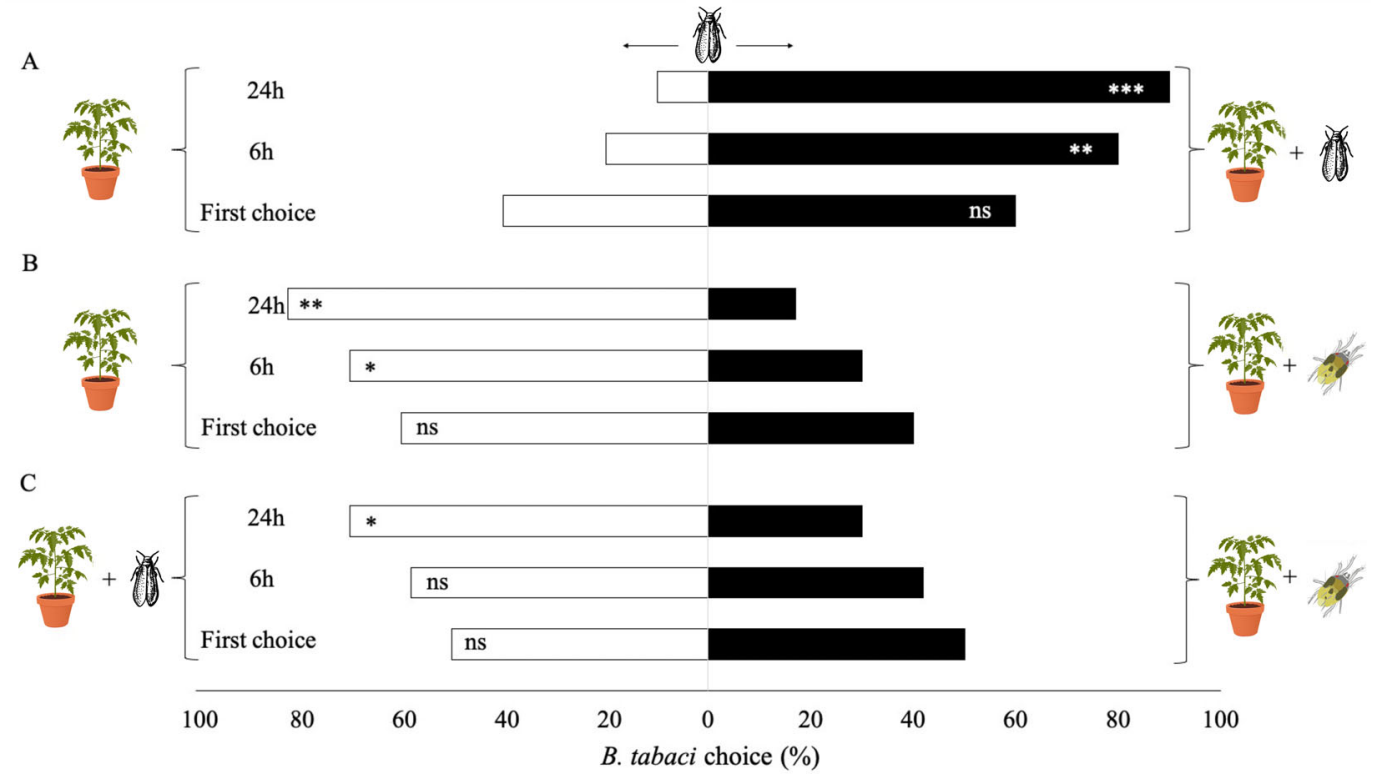

Figure 3. Number of Bemisia tabaci males and females $(n=30)$ settling after 1 min (first choice) and after 6 and 24 h on (A) uninfested tomato plants vs B. tabaci-infested tomato plants, (B) uninfested tomato plants vs Tetranychus urticae-infested tomato plants, and (C) B. tabaci-infested tomato plants vs T. urticae-infested tomato plants. The horizontal axis represents the percentage of $B$. tabaci individuals that moved toward the chosen host plant. Chisquare test $\left(\chi^{2}\right):{ }^{* *} P<0.001,{ }^{* *} P<0.01,{ }^{*} P<0.05$, ns $P>0.05$.

uninfested and conspecific-infested tomato plants $(P>0.05)$, they laid more eggs on uninfested plants after $24 \mathrm{~h}$ (Fig. 5(b); $t=2.766 ; P=0.0247$ ). Finally, $T$. urticae females were found more often on $B$. tabaci-infested tomato plants than on conspecificinfested plants at 6 and $24 \mathrm{~h}$ (Fig. $4(\mathrm{c}) ; 6 \mathrm{~h}: \chi^{2}=4.6, P=0.038$; $24 \mathrm{~h}: \chi^{2}=6.32, P=0.012$ ), with larger numbers of eggs laid on B. tabaci-infested plants (Fig. 5(b); $t=3.340 ; P=0.007$ ).

\subsection{Plant gene expression analysis}

Analysis of the relative expression of genes showed transcriptional differences (Fig. 6). The ASR1 gene (a measure of ABA expression) and the PIN2 gene (involved in JA activation) were significantly up- regulated $\left(F_{2,6}=16.798, P=0.0034 ; F_{2,6}=7.864, P=0.0216\right)$ on $T$. urticae- and B. tabaci-infested plants compared to control plants (Fig. 6(a), (b)). In addition, $T$. urticae showed higher expression of the ARS1 gene compared to $B$. tabaci-infested plants $\left(F_{2,6}=23.632, P=0.0348\right)$ (Fig. 6 (a)). On the other hand, only $B$. tabaci-infested plants increased expression of the $P R 1$ gene (SA pathway-related) compared to control tomato plants $\left(F_{2,6}=8.322, P=0.0242\right)$ (Fig. $\left.6(\mathrm{c})\right)$.

\subsection{Analysis of plant volatiles}

Chemical analysis of selected volatile samples collected from uninfested and infested tomato plants revealed a blend consisting of 19 major compounds, of which 16 were common to all 
A

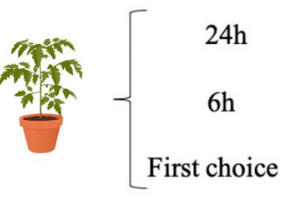

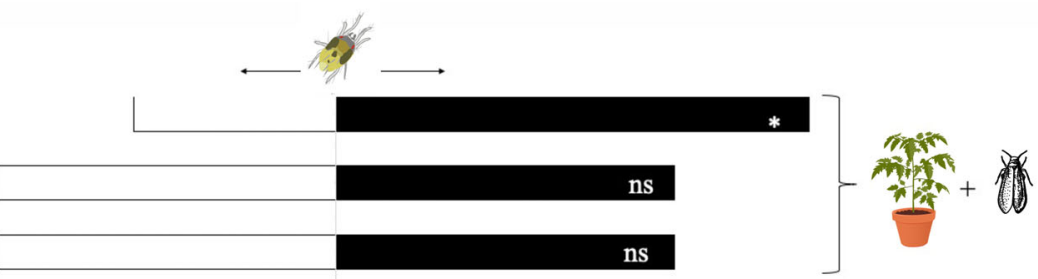

B
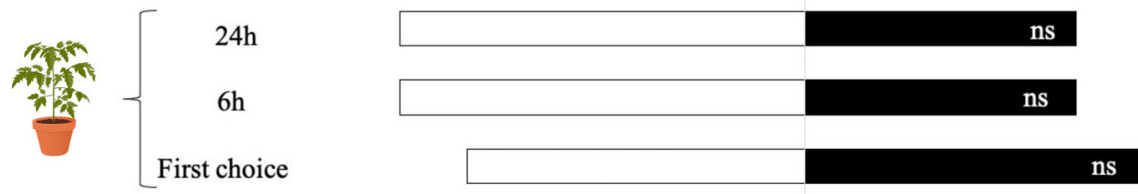

C

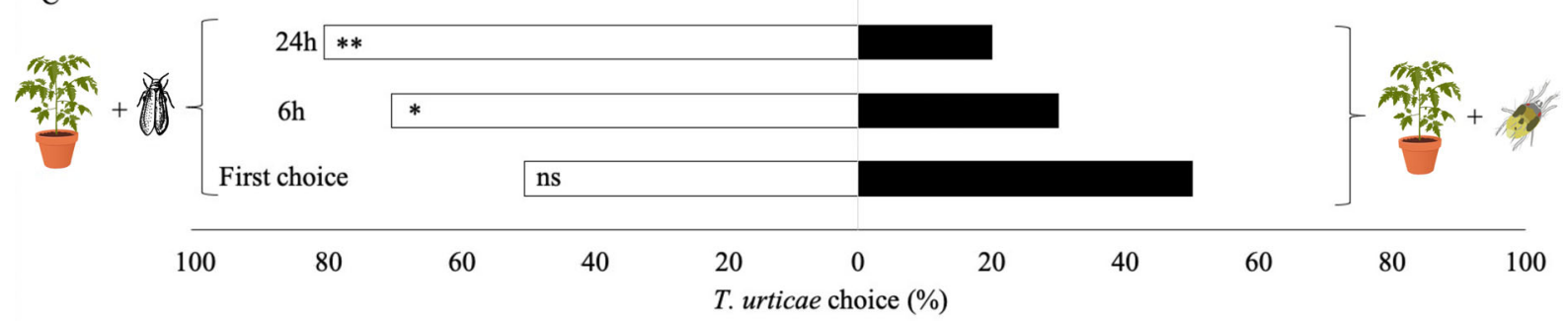

Figure 4. Number of Tetranychus urticae females ( $n=30$ settling after $1 \mathrm{~min}$ (first choice) and after 6 and $24 \mathrm{~h}$ on (A) uninfested tomato plants vs Bemisia tabaci-infested tomato plants, (B) uninfested tomato plants vs T. urticae-infested tomato plants, and (C) B. tabaci-infested tomato plants vs T. urticaeinfested tomato plants. The horizontal axis represents the percentage of $T$. urticae that moved toward the chosen host plant. Chi-square test $\left(\chi^{2}\right)$ : ${ }^{* * *} P<0.001,{ }^{* *} P<0.01,{ }^{*} P<0.05$, ns $P>0.05$.

A

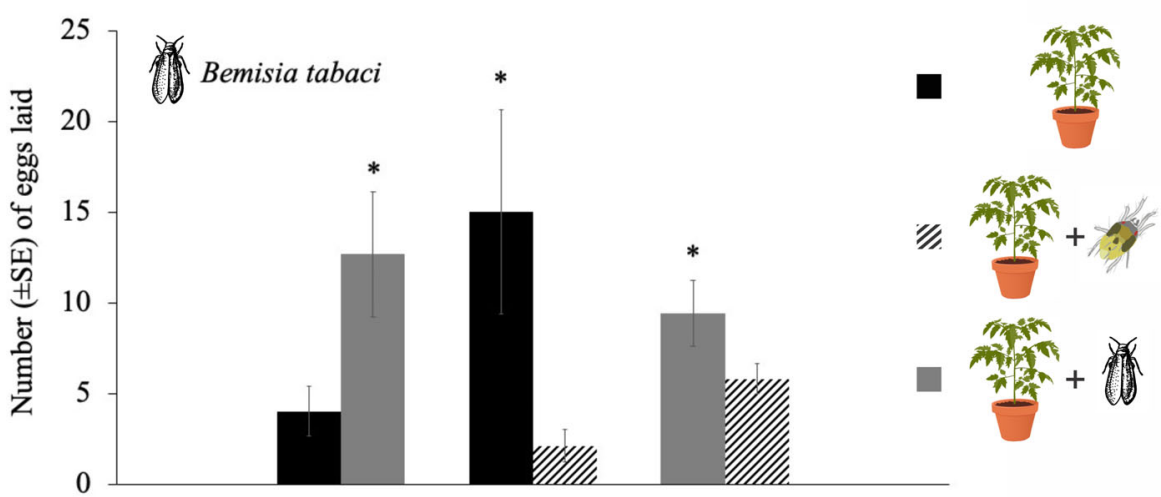

B

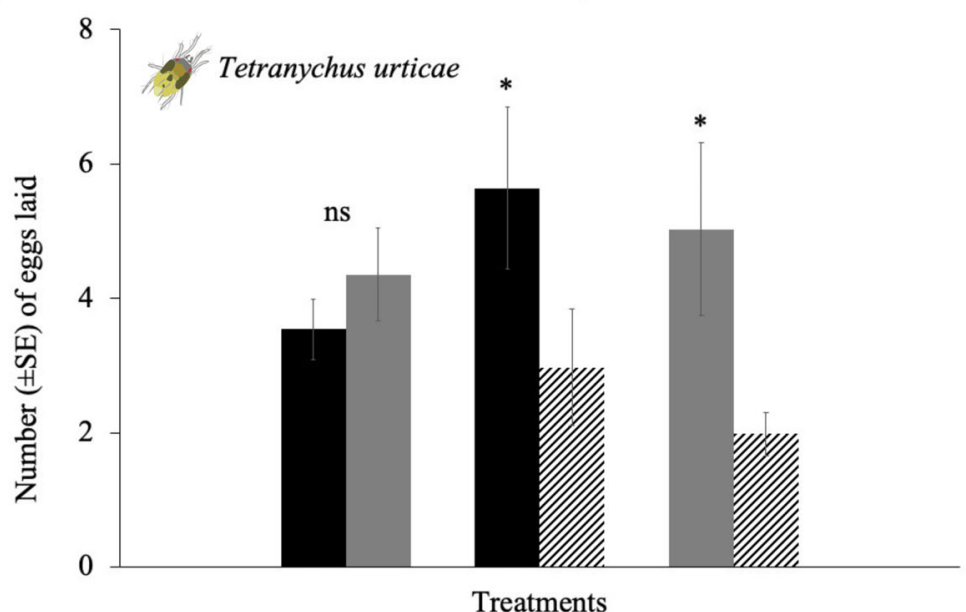

Figure 5. Oviposition (eggs/female $\pm \mathrm{SE}$ ) of Bemisia tabaci (A) and Tetranychus urticae (B) within $24 \mathrm{~h}$ when offered a choice between two of three treatments. Means in columns with an asterisk (*) within choice situations are significantly different between treatments $(P<0.05 ; t$-test for dependent samples). 


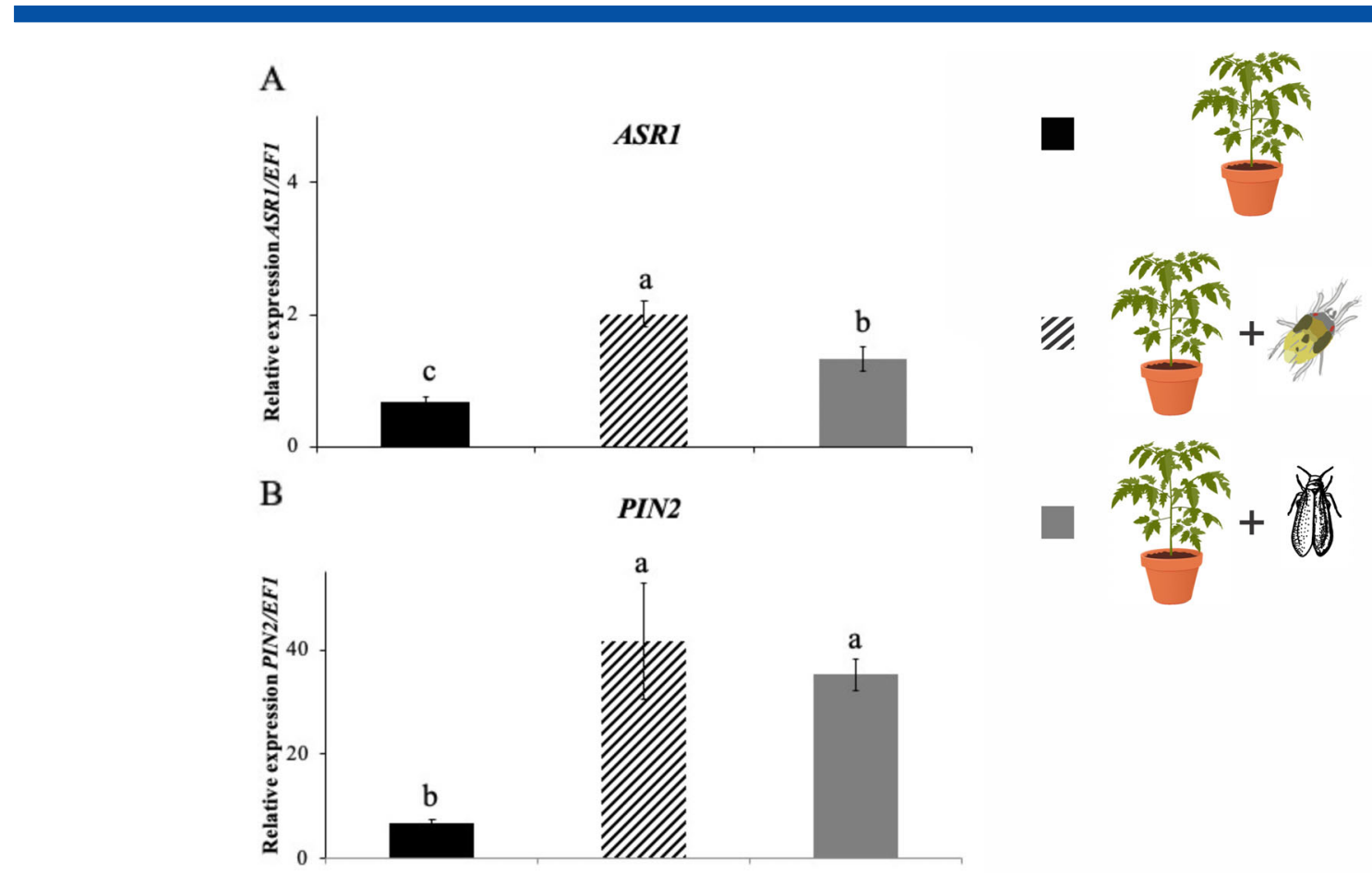

$\mathrm{C}$

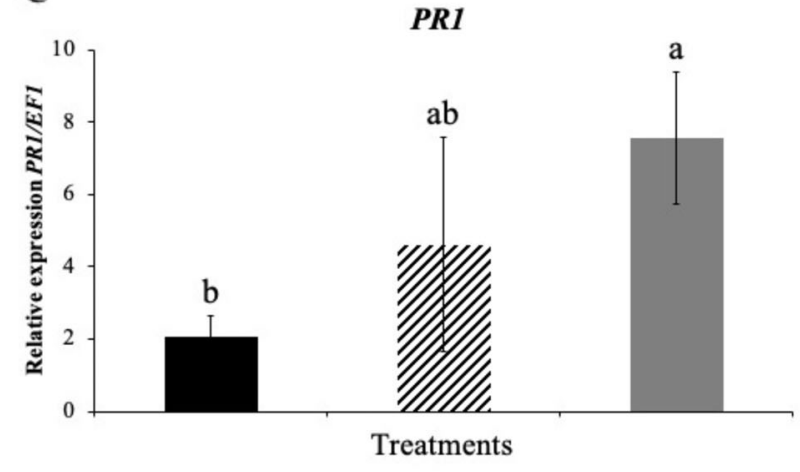

Figure 6. Expression analysis of $A S R 1$ (A), PIN2 (B), and PR1 (C) of the apical part of tomato plants in intact Tetranychus urticae-infested (24 $\mathrm{h}$ after infestation) and Bemisia tabaci-infested tomato plants (10 days after infestation). Transcription levels were normalized to the expression of $E F 1$ measured in the same sample. Data are presented as the mean of three independent analyses of transcript expression relative to a housekeeping gene \pm SE $(n=3)$. Significant differences were based on ANOVA, Tukey's test $\alpha<0.05$.

treatments but in different proportions (Table 2). Qualitative differences were found for two VOCs ((Z)-3-hexenol and $\beta$-ocimene), which were up-regulated in samples from the infested tomato plant treatments. Major quantitative differences were found for many VOCs among plants exposed to one of the two herbivory treatments. Both T. urticae and B. tabaci-infested plants emitted more total fatty-acid derivatives (FADs) (Kruskal-Wallis, $\mathrm{df}=2$, $P=0.0384$ ) and terpenes (Kruskal-Wallis, $\mathrm{df}=2, P=0.0235$ ) compared to uninfested tomato plants. Taken individually, particularly high concentrations of the ester methyl salicylate and the terpenoids $\alpha$-pinene and $\beta$-pinene were emitted by infested plants relative to uninfested plants.

These changes in the composition of volatiles affected the total production of volatiles (FADs, phenylpropanoids, and terpenes), which was higher in infested than in uninfested plants. No differences were observed between the mite-infested and whitefly-infested tomato plants (Kruskal-Wallis, $\mathrm{df}=2, P=0.02937$ ), (Table 2).
Multivariate analyses (PCA), which evaluated the influence of each compound on the blend, showed different patterns of treatment grouping, where the blends from two herbivory treatments were distinct from the undamaged control plants and from each other, which contributed $\sim 44 \%$ of the variance (Fig. 7 ). The separation was influenced mainly by the herbivore treatment, where the terpenoids $\beta$-ocimene, $\beta$-elemene, and linalool were highly correlated with $T$. urticae infestation, whereas the ester methyl salicylate, indole, and carene were highly correlated with B. tabaci-infested plants.

\section{DISCUSSION}

Knowledge of host-plant selection is essential to understand the interactions between herbivorous insects and host plants. The outcomes of interspecific insect interactions mediated by plant volatiles are often variable and inconsistent, and can influence the species richness in ecosystems, affecting the population 
Table 2. Relative amounts of volatile emissions (mean \pm SE ng g shoot dry weight) by control uninfested tomato plants, Tetranychus urticae-infested tomato plants, and Bemisia tabaci-infested tomato plants. Quantification was based on the peak area relative to the peak area of the internal standard. Plant headspaces are given separately and grouped according to their chemical type

\begin{tabular}{|c|c|c|c|c|}
\hline \multirow[b]{2}{*}{$N$} & \multicolumn{4}{|c|}{ Treatments } \\
\hline & Compound & $\begin{array}{l}\text { Control } \\
(n=6)\end{array}$ & $\begin{array}{l}\text { Tetranychus } \\
\text { urticae- } \\
\text { infested } \\
(n=6)\end{array}$ & $\begin{array}{l}\text { Bemisia } \\
\text { tabaci- } \\
\text { infested } \\
(n=6)\end{array}$ \\
\hline \multicolumn{5}{|c|}{ Fatty-acid derivatives } \\
\hline 1 & (Z)-3-hexenol & n.d. & $0.3 \pm 0.1$ & $2.8 \pm 0.9$ \\
\hline 2 & Hexanal & $0.4 \pm 0.1$ & $0.8 \pm 0.3$ & $1.2 \pm 0.5$ \\
\hline \multirow[t]{2}{*}{3} & Hexenyl acetate & $0.09 \pm 0.03$ & $1.7 \pm 0.2$ & $1.1 \pm 0.3$ \\
\hline & $\begin{array}{l}\text { Total } \\
\text { Aromatic } \\
\quad \text { heterocyclic }\end{array}$ & $0.49 \pm 0.13 a$ & $1.8 \pm 0.6 b$ & $5.1 \pm 1.0 c$ \\
\hline \multirow[t]{2}{*}{4} & Indole & $1.3 \pm 0.4$ & $0.9 \pm 0.3$ & $1.9 \pm 0.4$ \\
\hline & Phenylpropanoid & & & \\
\hline \multirow[t]{2}{*}{5} & Methyl salicylate & $8.0 \pm 2.4$ & $18.3 \pm 3.6$ & $30.3 \pm 7.8$ \\
\hline & Terpenes & & & \\
\hline 6 & $\alpha$-pinene & $1.6 \pm 0.1$ & $12.0 \pm 0.13$ & $6.8 \pm 2.1$ \\
\hline 7 & $\beta$-pinene & $1.4 \pm 0.1$ & $10.4 \pm 0.2$ & $7.8 \pm 2.5$ \\
\hline 8 & Ocimene & n.d. & $3.4 \pm 0.9$ & $0.8 \pm 0.4$ \\
\hline 9 & $\beta$-elemene & $1.8 \pm 0.1$ & $2.7 \pm 0.9$ & $2.0 \pm 0.3$ \\
\hline 10 & Myrcene & $1.6 \pm 0.1$ & $2.7 \pm 0.8$ & $1.0 \pm 0.3$ \\
\hline 11 & $\beta$-phellandrene & $2.2 \pm 1.0$ & $2.0 \pm 0.6$ & $1.8 \pm 0.2$ \\
\hline 12 & $\mathrm{DMNT}^{\mathrm{a}}$ & $0.6 \pm 0.3$ & $3.2 \pm 0.7$ & $0.8 \pm 0.2$ \\
\hline 13 & Linalool & $0.9 \pm 0.1$ & $1.3 \pm 0.2$ & $1.0 \pm 0.2$ \\
\hline 14 & $\delta$-limonene & $1.8 \pm 0.4$ & $3.0 \pm 0.6$ & $2.1 \pm 0.9$ \\
\hline 15 & $\gamma$-terpinene & $4.1 \pm 1.7$ & $8.8 \pm 2.3$ & $10.7 \pm 3.6$ \\
\hline 16 & Carene & $2.4 \pm 0.6$ & $3.3 \pm 1.8$ & $5.9 \pm 1.9$ \\
\hline 17 & Caryophyllene & $2.0 \pm 1.4$ & $4.9 \pm 1.1$ & $7.3 \pm 2.0$ \\
\hline \multirow[t]{3}{*}{18} & (Z) $\beta$-farnesene & $0.6 \pm 0.1$ & $0.8 \pm 0.3$ & $1.0 \pm 0.2$ \\
\hline & Total & $22.8 \pm 7.2 \mathrm{a}$ & $56.7 \pm 9.9 b$ & $51.8 \pm 14.8 b$ \\
\hline & $\begin{array}{l}\text { Total } \\
\text { production }\end{array}$ & $32.5 \pm 11.1 \mathrm{a}$ & $73.7 \pm 16.9 b$ & $91.1 \pm 30 b$ \\
\hline \multicolumn{5}{|c|}{$\begin{array}{l}\text { Means followed by different letters indicate a significant difference } \\
\text { between treatments based on the nonparametric Kruskal-Wallis test } \\
(P<0.05) \text { and subsequent pairwise comparisons using the Monte } \\
\text { Carlo method. } \\
\text { a DMNT, 4,8-dimethylnona-1,3,7-triene. }\end{array}$} \\
\hline
\end{tabular}

growth of each other. ${ }^{45,46}$ Here, we examined the role of tomato HIPVs in the preference behavior of two herbivores that both attack tomato plants and change the host plant's defenses. ${ }^{7,55}$ These tomato pests, the whitefly $B$. tabaci and the two-spotted spider mite $T$. urticae, coexist in the field. Our data indicated that the sequence of infestation is an important factor in colonization by tomato pests. Depending on which pest species arrives first, the subsequently arriving species could be attracted or repelled.

\subsection{Whitefly response to conspecific- or heterospecific- infested plants}

B. tabaci adult females did not recognize the odors of uninfested potential host plants. Whiteflies are highly influenced by visual cues to host-plant location; ${ }^{56,57}$ however, they showed a strong preference for and increased oviposition on plants that were previously colonized by conspecifics. This preference is likely to be adaptive for $B$. tabaci, as by using the conspecific-induced tomato volatiles, which may act as an aggregation kairomone, ${ }^{58}$ they

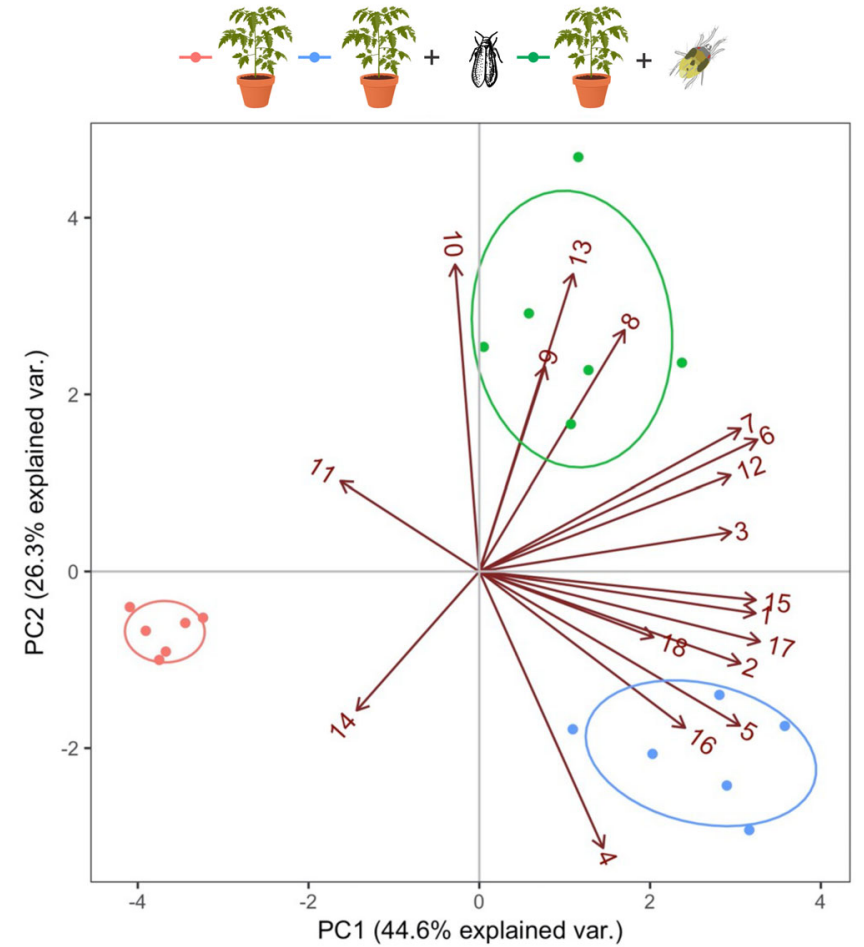

Figure 7. Principal components analysis (PCA) of the composition of volatiles emitted by uninfested tomato plants and tomato plants infested with Tetranychus urticae or Bemisia tabaci. Vector numbers correspond to compound numbers in Table 2.

increased their fecundity by $68 \%$ compared to the fecundity on uninfested control plants. These findings are in line with the observations of Su et al., ${ }^{22}$ who reported increased whitefly attraction to tomato plants that had been infested for 3 days. Also, whitefly-infested tobacco plants induced a higher rate of oviposition by conspecifics. ${ }^{59}$ The increased susceptibility of whiteflyinfested tomato plants to conspecifics in our system suggests that B. tabaci manipulates plant defenses, especially those related to the SA pathway, making the plant more attractive and suitable for whitefly development. ${ }^{60,61}$ With the SA-pathway activation, we expected a down-regulation of JA because of the known negative crosstalk between SA and JA, but the JA-related PIN2 gene was also activated. Despite the well-documented reciprocal inhibition, the relationship between SA and JA is not always antagonistic. Liu et al. ${ }^{62}$ observed that SA accumulation can activate the early induction of JA-responsive genes and de novo JA synthesis. Also, a low concentration of SA can neutralize the repellent effect of activated $J A$ on herbivore behavior, ${ }^{63}$ resulting in a higher preference for $B$. tabaci-infested plants. Activation of similar SA-related genes was also reported on tomato plants infested by the greenhouse whitefly Trialeurodes vaporariorum (Westwood) and on tobacco plants infested with B. tabaci, ${ }^{64}$ increasing their attractiveness to the whiteflies. ${ }^{58}$ Furthermore, whitefly-induced tomato-plant volatiles prime SA-dependent defenses, thus rendering neighboring tomato plants more susceptible to whiteflies. ${ }^{55}$

Through phytohormone activation, certain compounds that were elicited during herbivory may act as herbivore-specific cues or species-specific cues. ${ }^{65,66}$ Plant volatiles include a wide range of active substances such as green leaf volatiles (GLVs), phenylpropanoids, and terpenes, which can function as airborne signals 
responsible for insect-plant interactions. Our results demonstrate that plant infestation by $B$. tabaci stimulated changes in emissions of plant volatiles, since PCA analysis demonstrated a clear separation of infested plants from intact plants. Additionally, the volatile headspace analysis showed enhanced emissions of the same compound after infestation by $B$. tabaci on tomato plants. ${ }^{58,67,68}$ Among the emitted compounds, the ester methyl salicylate (MeSa), an airborne messenger molecule associated with activation of the SA defense pathway, plays an important role in tomato pest management. The controlled release of MeSA using emitting lures, besides acting as an attractant for natural enemies, ${ }^{69,70}$ repels $B$. tabaci individuals. ${ }^{71}$ In addition, tomato plants exposed to MeSa increased their emission of volatile compounds that repel three important tomato pests: Tuta absoluta (Meyrick) (Lepidoptera: Gelichiidae), B. tabaci, and Frankliniella occidentalis Pergande (Thysanoptera: Thripidae) ${ }^{72}$

Plant responses to colonizing herbivores are variable and highly context-dependent. Previous studies have confirmed that HIPVs also act as repellents of arthropod pests. ${ }^{16,73,74}$ We have previously shown that $B$. tabaci does not recognize the odor of uninfested tomato plants. However, we observed a preference for uninfested tomato plants over plants infested with mites, indicating that $B$. tabaci might be repelled by volatiles associated with a previous attack by T. urticae. Similarly, the aphid Chaetosiphon fragaefolii (Cockerell) (Hemiptera: Aphidae) was more attracted to uninfested strawberry plants than to plants with T. urticae damage. ${ }^{15}$ The performances of another whitefly, T. vaporariorum, and the coffee leaf miner Leucoptera coffeella Guérin-Méneville (Lepidoptera: Lyonetiidae) were also affected by previous infestations of $T$. urticae on strawberry and coffee plants, respectively. ${ }^{75,76}$ These observations concord with earlier findings that most strains of $T$. urticae induce plant defenses ${ }^{77,78}$ that subsequently deter arthropods from attacking.

The $86 \%$ reduction in the mean number of eggs laid on miteinfested plants compared to uninfested tomato plants can be attributed to secondary metabolites released by $T$. urticaeinfested plants, which can be toxic or simply act as a repellent to the arthropod. ${ }^{7}$ This low oviposition rate agrees with the increased expression of the ASR1 and PIN2 genes, markers of the ABA and JA pathways, respectively, ${ }^{17,79}$ which cause the synthesis of certain compounds such as polyphenol oxidases and different amino acids, protein inhibitors, which are reported to negatively affect the performance of herbivores. ${ }^{7,21,28,63,76}$

Tomato spider mites produce protein effectors that activate plant defenses, such as a proteinase inhibitor, as part of their colonization process, and it is reasonable to speculate that these protein effectors are also responsible for heterospecific repellence. ${ }^{28}$ Hence, our data indicated that the molecular processes stimulated by mite infestation, such as the expression of defense genes (JA and ABA-related), and consequently the induction of large amounts of certain volatile compounds such as limonene, $\alpha$-pinene, myrcene, and ocimene, might cause this whitefly avoidance of plants previously colonized by $T$. urticae. Indeed, Du et al. ${ }^{80}$ observed that whiteflies were repelled by a synthetic version of the same volatiles produced in larger quantities by mite-infested plants. Defensive allelochemicals such as those mentioned above, as well as other terpenes found in high concentrations in infested tomato plants, ${ }^{58}$ are also reported to repel many herbivore species, including whiteflies. ${ }^{68,81,82}$ In the case of virus-transmitting insects, the use of a synthetic volatile compound to alter the choice behavior before the insect lands and feeds is crucial to prevent the devastating effects of infection. ${ }^{57}$ An experiment on host-related behavior in cage conditions showed that
B. tabaci was less likely to rest on mite-punctured plants than on intact plants. This lower preference might be a consequence of induction of direct defenses mediated by mites. ${ }^{83}$ Volatile compounds inside the cage might become mixed, and therefore differences in preference may be attributed to the contact and feeding on plants with a high JA content and proteinase inhibitor (PI) activity (induction of PI by spider mites in tomato is jasmonatedependent), ${ }^{77,83}$ which can deter feeding by arthropod pests. ${ }^{40}$

\subsection{Response of two-spotted spider mite to conspecific- or heterospecific-infested plants}

Mites seem to resemble whiteflies in their repellence response to T. urticae-infested tomato plants. A subsequent infestation by two species of Tetranychidae, T. evansi and T. ludeni Zacher, is negatively affected, with decreased oviposition and population density. ${ }^{21,84}$ Although in the present study $T$. urticae females did not show a preference for uninfested or conspecific-infested tomato plants, the number of eggs laid on conspecific-infested plants was lower than on uninfested tomato plants. de Oliveira et al. ${ }^{28}$ also reported low numbers of eggs laid by $T$. urticae females on tomato plants that were previously infested by their conspecifics.

JA-dependent defenses seem to be important in plant resistance to spider mites. ${ }^{7,39,85,86}$ For instance, application of methyl jasmonate (MeJA), a product of the JA pathway, to susceptible citrus plants could re-establish resistance to mites in a highly susceptible phenotype. ${ }^{87}$ Pérez-Hedo et al. ${ }^{86}$ also reported a decrease in the T. urticae population on infested tomato plants that showed up-regulation of the same defensive gene PIN2, which is often used as a stand-in for the quality of plants as a resource for herbivores. $^{87}$ This decrease could be correlated with low oviposition and performance of con- and heterospecific mites. ${ }^{31,84}$ Transcriptomic studies have confirmed that plant defenses against spider mites and insects are guided not only by the JA pathway but also by other plant hormones such as abscisic acid (ABA). ${ }^{88,89}$ The higher expression of the PIN2 and ASR1 genes, which are involved in the JA and ABA pathways, respectively, and the incapacity of these herbivores to overcome these defenses, ${ }^{29}$ together with the up-regulation of known repellent compounds such as hexenyl acetate, $\beta$-ocimene, and $\mathrm{DMNT}^{68,86,90}$ by $T$. urticae-infested tomato plants might explain why mite-infested tomato plants repel conspecific mites.

A preference of mites for tomato-plant volatiles was observed only after the plants were infested with the whitefly $B$. tabaci (the SA inducer). The mites chose to oviposit on plants infested with $B$. tabaci more rapidly when conspecific mite-infested plants were also offered as a choice. The observed change is consistent with elevated JA-related gene expression in $T$. urticae-infested plants, which repels conspecifics and hastens their choice decision.

In summary, the findings discussed above confirmed that key changes in host-plant metabolism were elicited by an herbivore attack. From an ecological perspective, our study revealed that whitefly infestation early in the season rendered the plant susceptible to subsequent infestations of conspecific and other phytophagous arthropods such as mites. On the other hand, it is evident that changes in the plant secondary metabolites induced by $T$. urticae infestation alters the HIPVs, which repel both con- and heterospecific herbivores. The three genes studied here did not correlate clearly with the blend of HIPVs obtained. Additional studies of the genes codifying enzymes responsible for the composition of the HIPV blend will be necessary to disentangle the induction pathways involved. From a practical perspective, HIPVs 
such as MeSa and some GLVs can be applied as a spray to induce plants to produce their own HIPV blends, which result in saturated repellent and attractant environments for pests and natural enemies, respectively. ${ }^{72}$ This sustainable approach, through eliciting plant defenses, has been tested in commercial tomato production; plants induced with the GLV (Z)-3-hexenyl propanoate were less susceptible to attack by the lepidopteran $T$. absoluta. ${ }^{91}$ In addition, previous studies have reported that the compounds that may affect arthropod repellence, the terpenes limonene, $\alpha$-pinene, myrcene, $\beta$-ocimene, and DMNT, play an important role in attracting natural enemies, including predatory mites, ${ }^{91-94}$ thus opening prospects for a push-pull strategy to simultaneously repel arthropod pests and attract beneficial arthropods. ${ }^{95,96}$ Another way to deploy semiochemicals is through tomato breeding programs aiming to increase the emission of specific volatile compounds such as $\beta$-ocimene and $\mathrm{DMNT}^{91,92}$ that might reduce infestations of tomato pests. ${ }^{94}$ Taking the molecular and behavioral findings from this study together with the above-mentioned pest-management approaches, the development of strategies based on semiochemicals will improve on existing strategies to manage these worldwide pests.

\section{ACKNOWLEDGEMENTS}

The authors thank the National Institute of Science and Technology Semiochemicals in Agriculture (FAPESP and CNPq, grant numbers 2014/50871-0 and 465511/2014-7, respectively). The research leading to these results was partially funded by the São Paulo Research Foundation (FAPESP; Process 2016/12771-0) and the Spanish Ministry of Science and Innovation, through project RTA2017-00073-00-00.

\section{CONFLICT OF INTEREST}

The authors declare no conflict of interest.

\section{REFERENCES}

1 Awmack CS, Leather SR, Ost H and Lant P, Quality and fecundity in herbivorous insects. Annu Rev Entomol 47:817-844 (2002).

2 Schoonhoven LM, Van Loon JJ and Dicke M, Insect-Plant Biology. Oxford University Press on Demand, Oxford (2005).

3 Bernays EA and Chapman RF, Host-Plant Selection by Phytophagous Insects. Springer Science \& Business Media, London (2007).

4 Diezel C, von Dahl CC, Gaquerel E and Baldwin IT, Different lepidopteran elicitors account for cross-talk in herbivory-induced phytohormone signaling. Plant Physiol 150:1576-1586 (2009).

5 Giordanengo P, Brunissen L, Rusterucci C, Vincent C, van Bel A, Dinant S et al., Compatible plant-aphid interactions: how aphids manipulate plant responses. C R Biol 333:516-523 (2010).

6 Inbar M and Gerling D, Plant-mediated interactions between whiteflies, herbivores, and natural enemies. Annu Rev Entomol 53:431448 (2008).

7 Agut B, Pastor V, Jaques JA and Flors V, Can plant defence mechanisms provide new approaches for the sustainable control of the twospotted spider mite Tetranychus urticae? Int J Mol Sci 19:614 (2018).

8 Dicke $M$, Behavioural and community ecology of plants that cry for help. Plant Cell Environ 32:654-665 (2009).

9 Holopainen JK and Gershenzon J, Multiple stress factors and the emission of plant VOCs. Trends Plant Sci 15:176-184 (2010).

10 Szendrei Z and Rodriguez-Saona C, A meta-analysis of insect pest behavioral manipulation with plant volatiles. Entomol Exp Appl 134:201-210 (2010).

11 Rodriguez-Saona C, Chalmers JA, Raj S and Thaler JS, Induced plant responses to multiple damagers: differential effects on an herbivore and its parasitoid. Oecologia 143:566-577 (2005).
12 Pérez-Hedo M and Urbaneja A, Prospects for predatory mirid bugs as biocontrol agents of aphids in sweet peppers. J Pest Sci 88:65-73 (2015).

13 El-Sayed AM, Knight AL, Basoalto E and Suckling DM, Caterpillarinduced plant volatiles attract conspecific herbivores and a generalist predator. J Appl Entomol 142:495-503 (2018).

14 Bouagga S, Urbaneja A, Rambla JL, Flors V, Granell A, Jaques JA et al., Zoophytophagous mirids provide pest control by inducing direct defences, antixenosis and attraction to parasitoids in sweet pepper plants. Pest Manage Sci 74:1286-1296 (2018a).

15 Cédola CV, Gugole OMF, Brentassi ME, Cingolani MF and Greco NM, Negative interaction between twospotted spider mites and aphids mediated by feeding damage and honeydew. Bull Entomol Res 103:233-240 (2013).

16 Agut B, Gamir J, Jaques JA and Flors V, Tetranychus urticae-triggered responses promote genotype-dependent conspecific repellence or attractiveness in citrus. New Phytol 207:790-804 (2015).

17 Pérez-Hedo $M$, Urbaneja-Bernat $P$, Jaques JA, Flors $V$ and Urbaneja $A$, Defensive plant responses induced by Nesidiocoris tenuis (Hemiptera: Miridae) on tomato plants. J Pest Sci 88:543-554 (2015a).

18 Pérez-Hedo M, Bouagga S, Jaques JA, Flors V and Urbaneja A, Tomato plant responses to feeding behavior of three zoophytophagous predators (Hemiptera: Miridae). Biol Control 86:46-51 (2015b).

19 Bouagga S, Urbaneja A, Rambla JL, Granell A and Pérez-Hedo M, Orius laevigatus strengthens its role as a biological control agent by inducing plant defenses. J Pest Sci 91:55-64 (2018b).

20 Viswanathan DV, Lifchits OA and Thaler JS, Consequences of sequential attack for resistance to herbivores when plants have specific induced responses. Oikos 116:1389-1399 (2007).

21 Sarmento RA, Lemos F, Bleeker PM, Schuurink RC, Pallini A, Oliveira MGA et al., A herbivore that manipulates plant defence. Ecol Lett 14:229-236 (2011).

22 Su Q, Chen G, Mescher MC, Peng Z, Xie W, Wang S et al., Whitefly aggregation on tomato is mediated by feeding-induced changes in plant metabolites that influence the behaviour and performance of conspecifics. Funct Ecol 32:1180-1193 (2018).

23 Peñaflor MFG, Andrade FM, Sales L, Silveira EC and Santa-Cecília LV, Interactions between white mealybugs and red spider mites sequentially colonizing coffee plants. J Appl Entomol 143:957-963 (2019).

24 Anderson $\mathrm{P}$ and Alborn $\mathrm{H}$, Effects on oviposition behaviour and larval development of Spodoptera littoralis by herbivore-induced changes in cotton plants. Entomol Exp Appl 92:45-51 (1999).

25 Horgan FG, Naik BS, Iswanto EH, Almazan MLP, Ramal AF and Bernal CC, Responses by the brown planthopper, Nilaparvata lugens, to conspecific density on resistant and susceptible rice varieties. Entomol Exp Appl 158:284-294 (2016).

26 Howe GA and Jander G, Plant immunity to insect herbivores. Annu Rev Plant Biol 59:41-66 (2008).

27 Rodriguez-Saona CR, Musser RO, Vogel H, Hum-Musser SM and Thaler JS, Molecular, biochemical, and organismal analyses of tomato plants simultaneously attacked by herbivores from two feeding guilds. J Chem Ecol 36:1043-1057 (2010).

28 de Oliveira EF, Pallini A and Janssen A, Herbivores with similar feeding modes interact through the induction of different plant responses. Oecologia 180:1-10 (2016).

29 Errard A, Baldermann S, Kühne S, Mewis I, Peterkin J and Ulrichs C, Interspecific interactions affect pests differently. Gesunde Pflanz 67: 183-190 (2015).

30 Lin D, Xu Y, Wu H, Liu X, Zhang L, Wang J et al., Plant defense responses induced by two herbivores and consequences for whitefly Bemisia tabaci. Front Physiol 10:346 (2019).

31 Greco NM, Pereyra PC and Guillade A, Host-plant acceptance and performance of Tetranychus urticae (Acari, Tetranychidae). J Appl Entomol 130:32-36 (2006).

32 Zhang PJ, Zheng SJ, van Loon JJA, Boland W, David A, Mumm R et al., Whiteflies interfere with indirect plant defense against spider mites in Lima bean. Proc Natl Acad Sci USA 106:21202-21207 (2009).

33 Stansly PA and Naranjo SE, Bemisia: Bionomics and Management of a Global Pest. Springer, Dordrecht (2010). https://doi.org/10.1007/ 978-90-481-2460-2.

34 Castagnoli M, Caccia R, Liguori M, Simoni S, Marinari S and Soressi GP, Tomato transgenic lines and Tetranychus urticae: changes in plant suitability and susceptibility. Exp Appl Acarol 31:177-189 (2003).

35 Stansly PA, Sánchez PA, Rodríguez JM, Cañizares F, Nieto A, López Leyva MJ et al., Prospects for biological control of Bemisia tabaci 
(Homoptera, Aleyrodidae) in greenhouse tomatoes of southern Spain. Crop Prot 23:701-712 (2004).

36 Inoue-Nagata AK, Lima MF and Gilbertson RL, A review of geminivirus diseases in vegetables and other crops in Brazil: current status and approaches for management. Hortic Bras 34:8-18 (2016).

37 Tomczyk A and Kropczynska D, Effects on the host plant, in Spider Mites, their Biology, Natural Enemies and Control, ed. by Helle W and Sabelis MW. Amsterdam, Elsevier Science Publishers, pp. 317329 (1985).

38 Park YL and Lee JH, Leaf cell and tissue damage of cucumber caused by two spotted spider mite (Acari: Tetranychidae). J Econ Entomol 95: 952-957 (2002).

39 Alba JM, Schimmel BC, Glas JJ, Ataide LM, Pappas ML, Villarroel CA et al., Spider mites suppress tomato defenses downstream of jasmonate and salicylate independently of hormonal crosstalk. New Phytol 205:828-840 (2015).

40 de Oliveira EF, Pallini A and Janssen A, Herbivore performance and plant defense after sequential attacks by inducing and suppressing herbivores. Insect Sci 26:108-118 (2017).

41 Schimmel BC, Ataide LM and Kant MR, Spatiotemporal heterogeneity of tomato induced defense responses affects spider mite performance and behavior. Plant Signal Behav 12:1688-1701 (2017).

42 Gharaei AM, Ziaaddini M, Jalali MA and Frerot B, Oviposition preference and olfactory response of Diaphania indica (Lepidoptera: Pyralidae) to volatiles of uninfested and infested cucurbitaceous host plants. Eur J Entomol 116:392-401 (2019).

43 Xu C, Wang X, Stansly PA and Ren S, Behavioral interactions between Bemisia tabaci (Homoptera: Aleyrodidae) and Tetranychus truncatus (Acarina: Tetranychidae). Fla Entomol 94:800-808 (2011).

44 Pappas ML, Tavlaki G, Triantafyllou A and Broufas G, Omnivoreherbivore interactions: thrips and whiteflies compete via the shared host plant. Sci Rep 8:3996 (2018).

45 Ohgushi T, Indirect interaction webs: herbivore-induced effects through trait change in plants. Annu Rev Ecol Evol Syst 36:81-105 (2005).

46 Kaplan I and Denno RF, Interspecific interactions in phytophagous insects revisited: a quantitative assessment of competition theory. Ecol Lett 10:977-994 (2007).

47 Lins JC Jr, van Loon JJA, Bueno VHP, Lucas-Barbosa D, Dicke M and van Lenteren JC, Response of the zoophytophagous predators Macrolophus pygmaeus and Nesidiocoris tenuis to volatiles of uninfested plants and to plants infested by prey or conspecifics. BioControl 59:707-718 (2014).

48 Villas Bôas GL, França FH and Macedo N, Potencial biótico da moscabranca Bemisia argentifolii a diferentes plantas hospedeiras. Hortic Bras 20:71-79 (2002).

49 Walzer A, Paulus HF and Schausberger P, Oviposition behavior of interacting predatory mites: response to the presence of con- and heterospecific eggs. J Insect Behav 19:305-320 (2006).

50 Dicke M, Chemical ecology of host-plant selection by herbivorous arthropods: a multitrophic perspective. Biochem Sys Ecol 28: 601-617 (2000).

51 López YIA, Martínez-Gallardo RR, López MG, Sánchez-Hernández C and Délano-frier J, Cross-kingdom effects of plant-plant signaling via volatile organic compounds emitted by tomato (Solanum lycopersicum) plants infested by the greenhouse whitefly (Trialeurodes vaporariorum). J Chem Ecol 38:1376-1386 (2012).

52 Anastasaki E, Balayannis G, Papanikolaou NE, Michaelakis AN and Milonas PG, Oviposition induced volatiles in tomato plants. Phytochem Lett 13:262-266 (2015).

53 Peñaflor MFGV, Mauck KE, Alves KJ, de Moraes CM and Mescher MC, Effects of single and mixed infections of Bean pod mottle virus and Soybean mosaic virus on host-plant chemistry and host-vector interactions. Funct Ecol 30:1648-1659 (2016).

54 Mauck KE, de Moraes CM and Mescher MC, Deceptive chemical signals induced by a plant virus attract insect vectors to inferior hosts. Proc Natl Acad Sci USA 107:3600-3605 (2010).

55 Zhang PJ, Wei JN, Zhao C, Zhang YF, Li CY, Liu SS et al., Airborne hostplant manipulation by whiteflies via an inducible blend of plant volatiles. Proc Natl Acad Sci USA 116:7387-7396 (2019).

56 van Lenteren JC and Noldus LPJJ, Whitefly-plant relationships: behavioural and ecological aspects, in Whiteflies: Their Bionomics, Pest Status and Management, Intercept Ltd. Intercept press, Andover, MA, pp. 47-89 (1990).
57 Fereres A, Peñaflor MFG, Favaro CF, Azevedo KE, Landi CH, Maluta NK et al., Tomato infection by whitefly-transmitted circulative and non-circulative viruses induce contrasting changes in plant volatiles and vector behaviour. Viruses 8:225-237 (2016).

58 Silva DB, Weldegergis BT, van Loon JJA and Bueno VHP, Qualitative and quantitative differences in herbivore-induced plant volatile blends from tomato plants infested by either Tuta absoluta or Bemisia tabaci. J Chem Ecol 43:53-65 (2017).

59 Xu HX, Qian LX, Wang XW, Shao RX, Hong Y, Liu SS et al., A salivary effector enables whitefly to feed on host plants by eliciting salicylic acid-signaling pathway. Proc Natl Acad Sci USA 116:490-495 (2019).

60 Zhang PJ, Xu CX, Zhang JM, Lu YB, Wei JN, Liu YQ et al., Phloem-feeding whiteflies can fool their host plants, but not their parasitoids. Funct Ecol 27:1304-1312 (2013).

61 Wang XW, Li P and Liu SS, Whitefly interactions with plants. Curr Opin Insect Sci 19:70-75 (2017).

62 Liu L, Sonbol FM, Huot B, Gu Y, Withers J, Mwimba M et al., Salicylic acid receptors activate jasmonic acid signalling through a non-canonical pathway to promote effector-triggered immunity. Nat Commun 7: 13099 (2016).

63 Wei J, van Loon JJ, Gols R, Menzel TR, Li N, Kang L et al., Reciprocal crosstalk between jasmonate and salicylate defence signalling pathways modulates plant volatile emission and herbivore hostselection behaviour. J Exp Bot 65:3289-3298 (2014).

64 Quintana-Camargo M, Méndez-Morán L, Ramirez-Romero R, GurrolaDíaz CM, Carapia-Ruiz V, Ibarra-Laclette E et al., Identification of genes differentially expressed in husk tomato (Physalis philadelphica) in response to whitefly (Trialeurodes vaporariorum) infestation. Acta Physiol Plant 37:29 (2015).

65 Stamps JA and Krishnan VV, Nonintuitive cue use in habitat selection. Ecology 86:2860-2867 (2005).

66 Shivaramu S, Jayanthi PDK, Kempraj V, Anjinappa R, Nandagopal B and Chakravarty AK, What signals do herbivore-induced plant volatiles provide conspecific herbivores? Arthropod Plant Interact 11: 815-823 (2017).

67 Silva DB, Bueno VH, van Loon JJ, Peñaflor MFG, Bento JMS and van Lenteren JC, Attraction of three mirid predators to tomato infested by both the tomato leaf mining moth Tuta absoluta and the whitefly Bemisia tabaci. J Chem Ecol 44:29-39 (2018).

68 Schlaeger S, Pickett JA and Birkett MA, Prospects for management of whitefly using plant semiochemicals, compared with related pests. Pest Manage Sci 74:2405-2411 (2018).

69 James DG and Price TS, Field-testing of methyl salicylate for recruitment and retention of beneficial insects in grapes and hops. J Chem Ecol 30:1613-1628 (2004).

70 Gadino AN, Walton VM and Lee JC, Evaluation of methyl salicylate lures on populations of Typhlodromus pyri (Acari: Phytoseiidae) and other natural enemies in western Oregon vineyards. Biol Control 63:48-55 (2012).

71 Pérez-Hedo M, Rambla JL, Granell A and Urbaneja A, Biological activity and specificity of Miridae-induced plant volatiles. BioControl 63:203$213(2018 b)$.

72 Pérez-Hedo M, Alonso-Valiente M, Vacas S, Gallego C, Pons C, Arbona V, et al., Plant exposure to herbivore-induced plant volatiles: a sustainable approach through eliciting plant defenses. Journal of Pest Science. (2021). https://doi.org/10.1007/s10340-021-01334-x.

73 Saad KA, Mohamad Roff MN, Shukri M, Mirad R, Mansour SAA and Abuzid I, Behavioral responses of whitefly, Bemisia tabaci (Hemiptera: Aleyrodidae), in relation to sex and infestation status of their host plants. Aust J Entomol 6:95-99 (2013).

74 War AR, Sharma HC, Paulraj MG, War MY and Ignacimuthu S, Herbivore induced plant volatiles: their role in plant defense for pest management. Plant Signal Behav 6:1973-1978 (2011).

75 Teodoro AV, Tscharntke T and Klein AM, From the laboratory to the field: contrasting effects of multi-trophic interactions and agroforestry management on coffee pest densities. Entomol Exp Appl 131: 121-129 (2009).

76 Mortazavi N, Fathipour Y and Talebi AA, Interactions between twospotted spider mite, Tetranychus urticae and greenhouse whitefly, Trialeurodes vaporariorum on strawberry. Syst Appl Acarol 22:20832092 (2017).

77 Li CY, Williams MM, Loh YT, Lee GI and Howe GA, Resistance of cultivated tomato to cell content-feeding herbivores is regulated by the octadecanoid-signaling pathway. Plant Physiol 130:494-503 (2002) 
78 Kant MR, Sabelis MW, Haring MA and Schuurink RC, Intraspecific variation in a generalist herbivore accounts for differential induction and impact of host plant defences. Proc $R$ Soc London B 275:443-452 (2008).

79 Naselli M, Urbaneja A, Siscaro G, Jaques JA, Zappalà L, Flors V et al., Stage-related defense response induction in tomato plants by Nesidiocoris tenuis. Int J Mol Sci 17:1210 (2016).

80 Du WX, Han XQ, Wang YB and Qin YC, A primary screening and applying of plant volatiles as repellents to control whitefly Bemisia tabaci (Gennadius) on tomato. Sci Rep 6:22140 (2016).

81 Bernasconi ML, Turlings TC, Ambrosetti L, Bassetti P and Dorn S, Herbivore-induced emissions of maize volatiles repel the corn leaf aphid, Rhopalosiphum maidis. Entomol Exp Appl 87:133-142 (1998).

82 Shi XB, Chen G, Tian LX, Peng ZK, Xie W, Wu QJ et al., The salicylic acidmediated release of plant volatiles affects the host choice of Bemisia tabaci. Int J Mol Sci 17:1048 (2016).

83 Kant MR, Ament K, Sabelis MW, Haring MA and Schuurink RC, Differential timing of spider mite-induced direct and indirect defenses in tomato plants. Plant Physiol 135:483-495 (2004).

84 Godinho DP, Janssen A, Dias T, Cruz C and Magalhães S, Downregulation of plant defence in a resident spider mite species and its effect upon con- and heterospecifics. Oecologia 180:161-167 (2015).

85 Glas JJ, Alba JM, Simoni S, Villarroel CA, Stoops M, Schimmel BC et al., Defense suppression benefits herbivores that have a monopoly on their feeding site but can backfire within natural communities. BMC Biol 12:98 (2014).

86 Pérez-Hedo $M$, Arias-Sanguino ÁM and Urbaneja A, Induced tomato plant resistance against Tetranychus urticae triggered by the phytophagy of Nesidiocoris tenuis. Front Plant Sci 9:1419 (2018a).

87 Agut B, Gamir J, Jacas JA, Hurtado M and Flors V, Different metabolic and genetic responses in citrus may explain relative susceptibility to Tetranychus urticae. Pest Manage Sci 70:1728-1741 (2014).
88 Green TR and Ryan CA, Wound-induced proteinase inhibitor in plant leaves: a possible defense mechanism against insects. Science 175: 776-777 (1972).

89 Hillwig MS, Chiozza M, Casteel CL, Lau ST, Hohenstein J, Hernández E et al., Abscisic acid deficiency increases defence responses against Myzus persicae in Arabidopsis. Mol Plant Pathol 17:225-235 (2016).

90 Horiuchi Jl, Arimura Gl, Ozawa R, Shimoda T, Takabayashi J and Nishioka T, A comparison of the responses of Tetranychus urticae (Acari: Tetranychidae) and Phytoseiulus persimilis (Acari: Phytoseiidae) to volatiles emitted from lima bean leaves with different levels of damage made by $T$. urticae or Spodoptera exigua (Lepidoptera: Noctuidae). Appl Entomol Zool 38:109-116 (2003).

91 Shimoda T, Nishihara M, Ozawa R, Takabayashi J and Arimura G, The effect of genetically enriched $(E)$ - $\beta$-ocimene and the role of floral scent in the attraction of the predatory mite Phytoseiulus persimilis to spider mite-induced volatile blends of torenia. New Phytol 193 : 1009-1021 (2012).

92 Kappers IF, Hoogerbrugge $\mathrm{H}$, Bouwmeester $\mathrm{HJ}$ and Dicke M, Variation in herbivory-induced volatiles among cucumber (Cucumis sativus L.) varieties has consequences for the attraction of carnivorous natural enemies. J Chem Ecol 37:150-160 (2011).

93 Laznik Ž and Trdan S, Are synthetic volatiles, typically emitted by insect-damaged peach cultivars, navigation signals for twospotted lady beetle (Adalia bipunctata L.) and green lacewing (Chrysoperla carnea [Stephens]) larvae? J Plant Dis Protect 125: 529-538 (2018).

94 Aljbory $Z$ and Chen MS, Indirect plant defense against insect herbivores: a review. Insect Sci 25:2-23 (2018).

95 Xu Q, Hatt S, Lopes T, Zhang Y, Bodson B, Chen J et al., A push-pull strategy to control aphids combines intercropping with semiochemical releases. J Pest Sci 91:93-103 (2018).

96 Degenhardt J, Hiltpold I, Köllner TG, Frey M, Gierl A, Gershenzon J et al, Restoring a maize root signal that attracts insect-killing nematodes to control a major pest. Proc Natl Acad Sci USA 106:13213-13218 (2009). 